\title{
ANALYSIS OF CONSTRUCTION SERVICES INCOME TAX LAW
}

\author{
Nor Hasan, Heru Tjaraka \\ Faculty of Economics and Business, Airlangga University \\ AirlanggaStreet No.4, Airlangga, Gubeng, Surabaya, East Java 60286 \\ 0315033642,nor.hasan-2017@feb.unair.ac.id,norhasan1610@gmail.com
}

\begin{abstract}
Abstrak: Penelitian ini menganalisis kepastian hukum pengenaan pajak penghasilan atas jasa konstruksi yang dikenai Pajak Penghasilan bersifat Final dan Pajak Penghasilan bersifat Tidak Final serta menganalisis bentuk penyelesaian konflikhukum atas pengenaan Pajak Penghasilan pada sektor jasa konstruksi yang dapat memberikan kepastian hukum bagi pelaku usaha jasa konstruksi, terutama dalam hal penentuan kualifikasi usaha.Penelitian ini termasuk dalam jenis penelitian hukum normatif dengan pendekatan perundang-undangan (statute approach) dan pendekatan konseptual (conceptual approach). Analisis bahan hukum yang digunakan adalah dengan analisis sistematika hukum dengan menggunakan asas hukum dan ketentuan hukum yang berkaitanerat dengan pengenaan pajak atas jasa konstruksi, yang diperoleh melalui studi dokumentasi untuk mengidentifikasi pengertian pokok dan/atau dasar hak dan kewajiban, peristiwa hukum, hubungan hukum, dan objek hukum. Konflik hukum pada sektor pajak penghasilan jasa konstruksi dapatdiselesaikam dengan interpretasi yang telah memenuhi 3 (tiga) asas dalam contextualism dan asas preferensi hukum, yaitu asas lex superiori derogat legi inferiori. Dengan asas lex superiori derogat legi inferiori tersebut, Pasal 23 Undang - Undang Pajak Penghasilan (UU PPh) lebih unggul dari pada Pasal 3 Peraturan Pemerintah Nomor 51 Tahun 2008 juncto Peraturan Pemerintah Nomor 40 Tahun 2009.Pengenaan pajak denganPasal 4 Ayat (2) huruf d UU PPh yang bersifat final dikenakan pada Jasa Konstruksi yang memiliki kualifikasi usaha. Namun apabila tidak memiliki kualifikasi usaha, maka tidak dikenai Pasal 4 Ayat (2) huruf d UU PPh, melainkan dikenai Pasal $23 \mathrm{UU} \mathrm{PPh}$.
\end{abstract}

Kata Kunci : Kepastian Hukum, Pajak Penghasilan, Jasa Konstruksi

Abstract: This study aims to analyze the characteristics of construction services
subject to Final Income Tax and Non-Final Income Tax as well as to analyze the
form of conflict of the rules on the imposition of Income Tax on construction
service sector that can provide legal certainty, especially in the case of business
qualification determination. This research is a normative legal research with statute
approach and conceptual approach. The types of materials used are primary legal
materials, secondary legal materials, and non-legal materials. Technique of trace 
material technique is library study and internet access. The analysis of legal materials used is with legal systematic analysis using legal principles and legal provisions relating to the imposition of taxes on construction services, obtained through documentation studies to identify basic understanding of rights and obligations, legal events, legal relations, and the object of law. Conflict of rules in the income tax of construction services can be answered by interpretation that has fulfilled 3 (three) principles in contextualism and the principle of legal preferences, that is namely the principle of lex superiori derogat legi inferiori then Article 23 of the Income Tax Law is superior to Article 3 PP. 51 Year 2008 juncto PP. 40 Year 2009. So Article 4 Paragraph (2) Sub-Paragraph d of the Income Tax Law which is finalized shall be Construction Services which have business qualification and if not have business qualification then not subject to Article 4 Paragraph (2) Sub-Paragraph d of Income Tax Law, seafarers shall be subject to Article 23 of the Income Tax Law.

Keywords: Legal Certainty, Income Tax, Construction Service

\section{Introduction}

The taxation sector is able to provide an important role in the State Budget (APBN) in Indonesia. The increase in state revenues, especially from the taxation sector, contributed positively to efforts to reduce the volume and ratio of the budget deficit and the ratio of the country's debt stock to Gross Domestic Product (GDP). Taxes are an obligation of society as citizens, but tax problems continue ${ }^{1}$.

The construction services sector, in 2016 was in the third position of the source of economic growth in Indonesia with a contribution of 0.51 percent after the processing industry sector and the trade sector. However,

${ }^{1}$ Nor Hasan, "The Effect of Self Assessment System and Fiscal Services on Formal Compliance of Taxpayers (Study on Surabaya Middle Tax Office)", FEB Airlangga University, 2017, p. 1. the certainty of the imposition of income tax on construction services is still a problem that is often faced by actors in construction services.

Based on Law Number 7 of 1983 concerning Income Tax As Last Amended By Law Number 36 of 2008 (Income Tax Law), income is categorized into two categories, namely income which is included as an object of income tax and income which is not included in the tax object income. Then the income included as the object of income tax is further divided into two, namely the imposition of income tax is final and the imposition of income tax is not final. In this case including the imposition of income tax on construction services that have the imposition of income tax is final and the imposition of income tax is not final. The tax is final and not final for construction services in Indonesia as shown in table 1.1 below: 
Table 1.1

Difference in Article of Income Tax Imposition on Construction Services

\begin{tabular}{|c|c|c|}
\hline Explanation & $\begin{array}{c}\text { Construction } \\
\text { Services Business }\end{array}$ & Construction Service \\
\hline Legal basis & $\begin{array}{l}\text { Final PPh ((Article } 4 \\
\text { Paragraph (2) letter d } \\
\text { of Income Tax Law)) }\end{array}$ & $\begin{array}{l}\text { Non-Final Income Tax ((Article } 23 \\
\text { Paragraph (1) letter c number } 2 \text { Income } \\
\text { Tax Law)) }\end{array}$ \\
\hline Sound rule & $\begin{array}{l}\text { The income below } \\
\text { can be subject to final } \\
\text { tax: d. Income from } \\
\text { property transfer } \\
\text { transactions in the } \\
\text { form of land and / or } \\
\text { buildings, } \\
\text { construction services } \\
\text { business, real estate } \\
\text { business, and leasing } \\
\text { of land and / or } \\
\text { buildings. }\end{array}$ & $\begin{array}{l}\text { Rewards related to technical services, } \\
\text { management services, construction } \\
\text { services, consulting services, and other } \\
\text { services other than services that have } \\
\text { been deducted by Income Tax as referred } \\
\text { to in Article } 21 \text {. }\end{array}$ \\
\hline Nature of tax & Final & Not final \\
\hline
\end{tabular}

Source : Primary legal material that has been processed

Table 1.1 above shows that there are differences in income tax imposition on construction services. This is clearly seen by being arranged into two different chapters. Although by definition, there is no difference between the rules with each other regarding construction services as shown in table 1.2 below:

Table 1.2

Definition of Construction Services

\begin{tabular}{|c|c|c|}
\hline No & Legal Basis & Sound Rule \\
\hline 1 & $\begin{array}{l}\text { Article } 1 \text { number } 2 \text { PP No. } \\
51 \text { of } 2008 \text { concerning } \\
\text { Income Tax on Income } \\
\text { from Construction Services } \\
\text { Businesses }\end{array}$ & $\begin{array}{l}\text { Construction services are consultancy } \\
\text { services planning construction work, } \\
\text { construction work implementation services, } \\
\text { and construction work supervision } \\
\text { consulting services. }\end{array}$ \\
\hline 2 & $\begin{array}{l}\text { Article } 1 \text { Number } 1 \text { of Law } \\
\text { No. } 2 \text { of } 2017 \text { concerning } \\
\text { Construction Services }\end{array}$ & $\begin{array}{l}\text { Construction Services are construction } \\
\text { consulting services and / or construction } \\
\text { works. }\end{array}$ \\
\hline
\end{tabular}




\begin{tabular}{|l|l|l|}
\hline & $\begin{array}{l}\text { Article } 1 \text { Number } 2 \text { of Law } \\
\text { No. } 2 \text { of } 2017 \text { concerning } \\
\text { Construction Services }\end{array}$ & $\begin{array}{l}\text { Construction Consultancy is a service for } \\
\text { the whole or part of an activity which } \\
\text { includes the study, planning, design, } \\
\text { supervision and management of the } \\
\text { construction of a building. }\end{array}$ \\
\hline
\end{tabular}

Source : Primary legal material that has been processed

Table 1.2 above shows that there are no significant differences in general definitions or provisions regarding construction services, construction planners, construction works, and construction supervisors between law number 2 of 2017 concerning construction services (Construction Services Act) and government regulation number 51 Year 2008 as amended by government regulation number 40 of 2009 concerning income tax on income from construction services business (PP PPh Construction Services). While the comparison of the imposition of income tax rates on construction services regulated in article 4 paragraph (2) letter $\mathrm{d}$ and article 23 paragraph (1) letter c number 2 of the Income Tax Law, as shown in table 1.3 below :

Table 1.3

Difference in Income Tax Rates on Construction Services

\begin{tabular}{|c|c|c|c|c|}
\hline Explanation & \multicolumn{3}{|c|}{ Construction Services Business } & $\begin{array}{l}\text { Construction } \\
\text { Service }\end{array}$ \\
\hline \multirow{2}{*}{ Legal basis } & \multicolumn{3}{|c|}{$\begin{array}{l}\text { PP No. } 51 \text { of } 2008 \text { in conjunction with PP } \\
\text { No. } 40 \text { of } 2009\end{array}$} & $\begin{array}{c}\text { Article } 23 \\
\text { Paragraph (1) }\end{array}$ \\
\hline & Article & Rates & $\begin{array}{c}\text { Business } \\
\text { Qualifications }\end{array}$ & $\begin{array}{l}\text { Income Tax } \\
\text { Law }\end{array}$ \\
\hline \multirow{3}{*}{ Executor } & $\begin{array}{l}\text { Article } 3 \\
\text { paragraph } \\
\text { (1) letter a }\end{array}$ & $2 \%$ & $\begin{array}{l}\text { Service Providers who } \\
\text { have small business } \\
\text { qualifications }\end{array}$ & \multirow{3}{*}{$2 \%$} \\
\hline & $\begin{array}{l}\text { Article } 3 \\
\text { paragraph } \\
\text { (1) letter c }\end{array}$ & $3 \%$ & $\begin{array}{l}\text { Service Providers who } \\
\text { have medium business } \\
\text { qualifications or large } \\
\text { business qualifications }\end{array}$ & \\
\hline & $\begin{array}{l}\text { Article } 3 \\
\text { paragraph } \\
\text { (1) letter b }\end{array}$ & $4 \%$ & $\begin{array}{l}\text { Service Providers who } \\
\text { do not have business } \\
\text { qualifications }\end{array}$ & \\
\hline
\end{tabular}




\begin{tabular}{|l|l|c|l|}
\multirow{2}{*}{$\begin{array}{l}\text { Planner and } \\
\text { Supervisor }\end{array}$} & $\begin{array}{l}\text { Article 3 } \\
\text { paragraph } \\
\text { (1) letter d }\end{array}$ & $4 \%$ & $\begin{array}{l}\text { Service Providers who } \\
\text { have business } \\
\text { qualifications }\end{array}$ \\
\cline { 2 - 4 } & $\begin{array}{l}\text { Article 3 } \\
\text { paragraph } \\
\text { (1) letter e }\end{array}$ & $6 \%$ & $\begin{array}{l}\text { Service Providers who } \\
\text { do not have business } \\
\text { qualifications }\end{array}$ \\
\hline
\end{tabular}

Source : Primary legal material that has been processed

Table 1.3 shows that the tariff for income tax on construction services under Article 23 of the Income Tax Law is $2 \%$. While the tariff for income tax on construction services based on Article 4 paragraph (2) of the Income Tax Law is determined based on the qualifications of the business of the construction service provider issued by the Construction Services Development Agency.

However, the imposition of income tax on construction services based on the derivative rules of Article 4 paragraph (2) of the Income Tax Law has qualifications that do not have business qualifications. Meanwhile according to the Construction Services Law itself, there is no qualification without business qualifications. This shows that there is a conflict in the rules regarding the regulation of income tax on construction services, especially in the qualifications of not having business qualifications regulated also in the derivative rules of Article 4 paragraph (2) of the Income Tax Law.

Thus, the authors are interested in examining the existence of conflicts or customary rules governing the imposition of income tax on construction services, namely examining the conflict related rules that are important to be immediately carried out to find a solution because the construction services sector is one of the backers of Indonesia's national economy.

In accordance with the description of the background, problems can be formulated that need to be studied in this study, namely :

1. What are the characteristics of construction services subject to Final Income Tax and Non-Final Income Tax?

2. What is the form of conflict resolution rule for imposition of Income Tax in the construction service sector that can provide legal certainty?

\section{Research methods}

Types of research

This type of research used in legal research is aturantif legal research, or commonly referred to as juridical, which discusses doctrines or 

principles in the science of law ${ }^{2}$ which include ${ }^{3}$ :

a. Research on legal principles

b. Research on legal systematics

c. Research on the level of legal synchronization

d. Comparative legal research

\section{Research Approach}

The approach taken in this study is a statute approach, which is that a study must certainly use a statutory approach, because what will be examined is the various legal rules that are the focus as well as the central theme of a research ${ }^{4}$. This approach opens opportunities for researchers to learn whether there is consistency and compatibility between laws and regulations with other laws and regulations ${ }^{5}$.

In addition, this study also uses a conceptual approach, an approach that is carried out by understanding abstract elements that represent classes of phenomena in a field of study, in this case the existing legal rules ${ }^{6}$. This approach departs from the views and doctrines that develop in law. Understanding of these views and doctrines is a support for researchers in building a legal argument in solving legal issues faced ${ }^{7}$.

\section{Discussion: Tax Concept}

Prof. Dr. Rochmat Soemitro, SH define tax as people's contribution to the state treasury based on the law (which can be forced) by not getting lead (counterpart) services that can be directly shown and used to pay public expenses $^{8}$. Whereas the definition of tax according to the Act as stated in article 1 number (1) of the UU KUP, namely: "Tax is a compulsory contribution to the state owed by an individual or entity that is based on the law, by not getting compensation directly and used for state purposes for the greatest prosperity of the people".

2 Ibid., h. 24 .

${ }^{3}$ Soejono and H. Abdurrahman, Legal Research Methods, Mold Ke (Jakarta: PT. Rineka Cipta, 2003), p. 55.

${ }^{4}$ Johnny Ibrahim, Theory and Research Methods of Administrative Law, Print Out (Malang: Bayumedia Publishing, 2005), pp. 248-49.

${ }^{5}$ Syamsudin, Operationalization of Legal Research (Jakarta: PT. Raja Grafindo Persada, 2007), p. 58.

${ }^{6}$ loc. cit., h. 252.

${ }^{7}$ loc. cit., h. 60.

${ }^{8}$ Mardiasmo, Taxation, Revi Edition (Yogyakarta: CV Andi Offset, 2011), p. 1. 
From the definition, it can be concluded that taxes have the following elements :

1. Contributions from the community to the state

Countries that are entitled to collect taxes from the public. These contributions are in the form of money, not goods or services.

2. Under the law

Taxes are collected based on or according to a statutory regulation, so that they have the power to force.

3. Controversy

There is no reciprocal service directly from the state to the people who pay taxes.

4. Used to finance state expenses

Namely expenditures that benefit the wider community.

The concept of tax as mentioned above is a tax concept in terms of tax that functions as a budgetair, namely tax as a source of funds for the Government to finance general state expenditures to prosper the life of the nation. In addition, the tax has a regular function, namely tax is used as a tool to regulate the community both in the economic, social, and political fields with specific objectives.

The state as an organization that has the right to collect taxes must fulfill the tax collection requirements so as not to cause obstacles or resistance, namely ${ }^{9}$ :

1. Terms of Justice

In accordance with the objectives of the law, namely achieving justice, the law and implementation of tax collection must also be fair.

2. Juridical Terms

Tax collection must be based on the law because it can be coercive, the rights and obligations of taxpayers and taxpayers must be regulated therein. In Indonesia, taxes are regulated in Article 23 paragraph (2) of the 1945 Constitution.

\section{Economic Terms}

Tax collection must maintain economic life balance and must not interfere with the economic life of the community. Tax collection must not interfere with the smoothness of production and trade activities, so as to cause the economic downturn of the community.

4. Financial requirements

${ }^{9}$ Erly Suandy, Tax Law, Issue 5 (South Jakarta: Salemba Empat Publishers, 2011), p. 28. 
In accordance with the tax function as a source of state revenue, the costs of tax collection cannot be too large. That is, the costs incurred for collecting taxes should be smaller than tax revenues.

5. The Tax Collection System Must Be Simple ${ }^{10}$

A simple tax collection system will facilitate and encourage people to fulfill their tax obligations.

Tax collection by the state is not without foundation. Some theories that provide the basis of justification for tax collection carried out by the state are as follows ${ }^{11}$ :

1. Insurance Theory

The state protects the safety of lives, property, and the rights of its people. Therefore the people have to pay a tax that is likened to an insurance premium because they get the guarantee of protection. This insurance theory only provides a foundation, because basically this theory is not appropriate to underlie the existence of tax collection. The premium is not right when interpreted the same as tax, because the premium in this theory should be the same as the retribution that the contruction can be directly felt by the premium provider ${ }^{12}$.

2. Interest Theory

The division of the tax burden on the people is based on the interests (eg protection) of each person. The greater a person's interest in the country, the higher the tax must be paid.

3. Pikul Power Theory

The tax burden for all people must be the same weight, meaning that the tax must be paid according to the capacity of each person. To measure load power can be used 2 (two) approaches, namely:

a. Objective element, by looking at the amount of income or wealth someone has.

b. Subjective element, taking into account the magnitude of material needs that must be met.

This piculsion theory is applied in Income Tax (PPh), where new Taxpayers are subject to Income Tax if they earn income in excess of Non-Taxable Income (PTKP) for Individual Taxpayers and obtain operating profit for Corporate Taxpayers ${ }^{13}$.

\footnotetext{
${ }^{10}$ Mardiasmo,op. cit, h. 2

${ }^{11}$ Mardiasmo,op. cit, h. 3

${ }^{12}$ Wirawan B. Ilyas and Richard Burton, Tax Law, Issue 5 (Jakarta: Salemba Empat, 2010), p. 21.

${ }^{13}$ Erly Suandy, op. cit, h. 27
} 
4. Devotional Theory

The basis of justice for taxation lies in the relations between the people and their country. As dedicated citizens, the people must always realize that paying taxes is an obligation.

5. The Principle of Purchasing Power Principles

The basis of justice lies in the result of tax collection. That means collecting taxes means attracting purchasing power from community households for state households. Furthermore, the state will channel it back to the community in the form of maintaining community welfare. Thus the interests of the whole community are preferred.

Tax collection is grouped according to group, nature, and collection agencies. This grouping is done because each tax collected has different criteria for properties and uses. Provisions regarding taxation in Indonesia are regulated in the UU KUP. There is a tax differentiation or grouping based on a criterion, namely ${ }^{14}$ :

1. According to the Group

a. Direct tax, which is a tax that must be borne by taxpayers themselves and cannot be charged or delegated to others.

Example: Income Tax.

b. Indirect tax, which is a tax that can eventually be charged or delegated to another person.

Example: Value Added Tax (VAT).

2. According to its nature

a. Subjective Tax, which is a tax based on or based on the subject, in the sense of paying attention to the condition of the taxpayer.

Example: Income Tax.

b. Objective tax, that is, taxes that originate on the object, regardless of the taxpayer's own condition.

Example: VAT and Sales Tax on Luxury Goods (PPnBM)

\section{Concept of Income Tax}

Income Tax (PPh) is a direct tax that must be borne by taxpayers themselves and cannot be charged or delegated to others. That is, PPh is a tax that originates or is based on the subject, paying attention to the condition of the taxpayer himself, in the sense that the tax is imposed because there is a subject that meets the criteria set out in the tax regulations. so there is a certainty that if there is no tax subject, then clearly it cannot be subject to $\mathrm{PPh}^{15}$.

${ }^{14}$ Mardiasmo,op. cit, h. 5-6

${ }^{15}$ Erly Suandy, op. cit, h. 43 
The Income Tax Law regulates taxes on income or profits received or obtained by an individual or entity. The PPh Law regulates the tax subject, the tax object, and how to calculate and pay off the tax owed. The Income Tax Law also provides facilities for ease and relief for taxpayers in carrying out tax obligations. The PPh Law adheres to the material principle, meaning that the determination of the tax payable does not depend on the tax assessment letter ${ }^{16}$.

\section{Final Income Tax and Non-Final Income Tax}

Based on Law Number 7 of 1983 concerning Income Tax As Last Amended By Law Number 36 of 2008 (Income Tax Law), income is categorized into two categories, namely:

1. Income that is included as an object of income tax

2. Income that is not included in the income tax object in accordance with article 4 paragraph (3) of the Income Tax Law

Then the income included as the object of income tax is further divided into two, namely:

1. Imposing tax on objects of final income tax in accordance with article 4 paragraph (2) of the Income Tax Law

2. Imposing tax on the object of non-final income tax in accordance with article 4 paragraph (1) of the Income Tax Law

Distribution of Income Tax (PPh) into 2 (two) parts, namely Non-Final Income Tax and Final Income Tax based on the nature of the deduction and / or collection ${ }^{17}$. The nature of the deduction and / or collection of the Income Tax as shown in table 2.1 below:

Table 2.1

Nature of Withholding and / or Collection of Income Tax

\begin{tabular}{|l|c|c|}
\hline \multirow{2}{*}{ Imposition } & \multicolumn{2}{|c|}{ Nature of Income Tax } \\
\cline { 2 - 3 } & Not Final & Final \\
\hline $\begin{array}{l}\text { Income combined with other income subject to } \\
\text { general rates in the Annual Corporate Income Tax } \\
\text { Return? }\end{array}$ & Yes & No \\
\hline
\end{tabular}

\footnotetext{
${ }^{16}$ Mardiasmo,op. cit, h. 123

${ }^{17} \mathrm{http}: / /$ ortax.org/ortax/?mod=info\&page=show\&id=168\&list=1 accessed on 12 December 2018
} 
Costs related to generating, collecting and maintaining income subject to (Not Final / Final Income Tax) can be deducted?

Evidence of Cut (Non-Final / Final Income Tax) can be calculated as a tax credit for parties who are deducted and / or collected?

Source: Processed non-legal material

\section{Construction Service}

JasaConstruction services can clearly be seen by looking at the general definition through two regulations, namely the Construction Services Act and PP PPh Construction Services. According to article 1 number (1) of the Construction Services Act that Construction Services is a construction consultancy service and / or construction work.

Furthermore, the definition of construction consultancy is the overall service for some activities which include the study, planning, design, supervision and management of the construction of a building ((Article 1 number (2) of the Construction Services Act)). While the construction work is the whole or part of activities which include the construction, operation, maintenance, dismantling, and rebuilding of a building ((Article 1 number (3) of the Construction Services Law)).

The definition of construction services according to $\mathrm{PP} \mathrm{PPh}$ Construction Services is stated in article 1 numbers (2), numbers (3), numbers (4), numbers (5), and numbers (6), namely:

(2) Construction Services are consultancy services for construction work planning, construction work implementation services, and construction work supervision consulting services.

(3) Construction Work is the whole or part of a series of planning and / or implementation activities along with supervision which includes architectural, civil, mechanical, electrical, and environmental arrangements of each and every one of them to realize a building or other physical form.

(4) Construction Planning is the provision of services by individuals or bodies declared professional experts in the field of construction service planning who are able to realize work in the form of other physical building planning documents.

(5) Construction Implementation is the provision of services by individuals or bodies declared professional experts in the field of 
construction services that are able to carry out their activities to realize a planning result into a building form or other physical form, including integrated construction work, namely merging service functions in the model of planning, procurement and development (engineering, procurement and construction) as well as a model of design and build.

(6) Construction Supervision is the provision of services by individuals or bodies declared professional experts in the field of construction services supervision, who are capable of carrying out supervisory work from the beginning of the construction work to completion and delivery.

Construction Services Businesses in Indonesia, can be in the form of businesses of individuals or business entities, whether legal entities or not incorporated (Article 20 of the Construction Services Law). And to run the construction service business, construction service businesses are required to have a Construction Services Business License (IUJK) issued by the local government.

IUJK can be obtained by construction service businesses with the requirement that they have Construction Services Business Certificates (SBU) for construction service business entities and have a Work Skills Certificate (SKA) and / or Work Skills Certificate (SKTK) as evidenced by ownership of a Person's Business Registration Certificate (TDUP) for businesses of individual construction services issued by the Construction Services Development Agency (LPJK).

Business Entity Certificates (SBU) are proof of recognition of classifications and qualifications on the capabilities of Construction Services business entities including the results of equalization of capabilities of foreign Construction Services business entities (Article 1 number 11 of the Law on Construction Services). Business qualifications determine the limits of the ability of a Construction Services business to carry out Construction Services at the same time. The qualification of the construction service business entity based on Article 9 paragraph (2) of the National Construction Services Development Agency (LPJKN) Number 3 of 2017 concerning Certification and Registration of Construction Services Business Services includes:

a. small business;

b. medium business; and

c. big business.

While the qualifications of construction planning and supervisory services business entities are regulated in Article 8 paragraph (2) of the National Construction Services Development Agency (LPJKN) Number 4 of 2017 concerning Certification and Construction 
Planning and Supervision Services Business Registration including:

a. small business;

b. medium business; and

c. big business.

The qualifications of the construction planning, implementing and supervisory service business entities are in accordance with those stated in Article 20 paragraph (1) of the Construction Services Law, namely: "Business qualifications for business entities as referred to in Article 19 consist of:
a. small;
b. medium; and
c. big".

The Work Skills Certificate (SKA) is a certificate issued by the LPJK and given to construction experts who have met competency requirements based on scientific discipline, functions and / or certain expertise. While the Work Skills Certificate (SKTK) is a certificate issued by the LPJK and given to skilled construction workers who have met competency requirements based on scientific discipline, functions and / or certain skills.

Article 9 paragraph (1) LPJKN No. 3 of 2017 concerning Certification and Construction Peleksana Services Business Registration and Article 8 paragraph (1) LPJKN No. 4 of 2017 concerning Certification and Registration of Construction Planning and Supervision Services Businesses states that "Business Qualifications of Individuals of service for planners, implementers and construction supervisors cover the business qualifications of individuals with subqualification $\mathrm{P}^{\prime \prime}$.

SKA and / or SKTK is a requirement for obtaining an Individual Person Business Registration (TDUP), namely a certificate of proof of formal recognition of the level / depth of business capabilities of an individual planner, executor and business construction services service provider with sub-classification and business sub-qualification provisions.

\section{Income Tax on Construction Services}

The imposition of income tax on construction services has a final income tax and the imposition of income tax is not final. The imposition of income tax on construction services is specifically regulated in Article 4 Paragraph (2) letter $d$ of the final Income Tax Law and Article 23 Paragraph (1) letter $\mathrm{c}$ number 2 of the Income Tax Act which is not final.

The imposition of tax is final and not final for construction services in Indonesia clearly as shown in table 2.2 below:

Table 2.2

Imposition of Income Tax on Construction Services in Indonesia 


\begin{tabular}{|c|c|c|}
\hline Explanation & $\begin{array}{c}\text { Construction Services } \\
\text { Business }\end{array}$ & Construction Service \\
\hline Legal basis & $\begin{array}{l}\text { Final PPh ((Article } 4 \text { Paragraph } \\
\text { (2) letter d of Income Tax } \\
\text { Law)) }\end{array}$ & $\begin{array}{l}\text { Non-Final Income Tax } \\
\text { ((Article } 23 \text { Paragraph }(1) \\
\text { letter c number } 2 \text { Income Tax } \\
\text { Law)) }\end{array}$ \\
\hline Sound rule & $\begin{array}{l}\text { The income below can be } \\
\text { subject to final tax: d. Income } \\
\text { from property transfer } \\
\text { transactions in the form of } \\
\text { land and / or buildings, } \\
\text { construction services business, } \\
\text { real estate business, and leasing } \\
\text { of land and / or buildings. }\end{array}$ & $\begin{array}{l}\text { Rewards related to technical } \\
\text { services, management } \\
\text { services, construction } \\
\text { services, consulting services, } \\
\text { and other services other than } \\
\text { services that have been } \\
\text { deducted by Income Tax as } \\
\text { referred to in Article } 21 \text {. }\end{array}$ \\
\hline Nature of tax & Final & Not final \\
\hline
\end{tabular}

Source : Primary legal material that has been processed

From table 2.2 above, it can be seen that the imposition of income tax on construction services is divided into two, namely final income tax based on Article 4 Paragraph (2) letter d of Income Tax Law and income tax that is not final based on Article 23 Paragraph (1) letter c number 2 Law on Income Tax.

In addition, regarding the amount of the final income tax rate for construction services, it is regulated in Article 4 Paragraph (2) letter $\mathrm{d}$ of the Income Tax Law which has a derivative regulation in the form of $\mathrm{PP}$ No. 51 of 2008 juncto PP No. 40 of 2009 and the amount of the non-final income tax rate for construction services is regulated in Article 23 Paragraph (1) letter c number 2 of the Income Tax Law.
The final income tax rate for construction services based on Article 4 paragraph (2) of the Income Tax Law is determined based on the qualifications of the business of the construction service provider. Construction service providers who have small business qualifications are subject to a $2 \% \mathrm{PPh}$ rate, Construction service providers who have medium business qualifications or large business qualifications are subject to a $3 \% \mathrm{PPh}$ tariff, Construction service providers who do not have business qualifications are subject to a $4 \% \mathrm{PPh}$ rate, Planner and Construction service supervisors who have business qualifications are subject to a $4 \% \mathrm{PPh}$ rate, and Planners and Supervisors of construction services who do not have business qualifications are subject to a $6 \% \mathrm{PPh}$ rate. Whereas the non-final 
income tax rate for construction $2 \%$.For more details, it can be seen in services is based on Article 23 of the more detail as shown in table 2.3 Income Tax Law, which is equal to below:

Table 2.3

Income Tax Rates on Construction Services

\begin{tabular}{|c|c|c|c|c|}
\hline Explanation & \multicolumn{3}{|c|}{ Construction Services Business } & $\begin{array}{l}\text { Construction } \\
\text { Service }\end{array}$ \\
\hline \multirow{2}{*}{ Legal basis } & \multicolumn{3}{|c|}{$\begin{array}{l}\text { PP No. } 51 \text { of } 2008 \text { in conjunction with } \\
\text { PP No. } 40 \text { of } 2009\end{array}$} & $\begin{array}{c}\text { Article } 23 \\
\text { Paragraph }(1)\end{array}$ \\
\hline & Article & Rates & $\begin{array}{c}\text { Business } \\
\text { Qualifications }\end{array}$ & $\begin{array}{l}\text { letter c of the } \\
\text { Income Tax Law }\end{array}$ \\
\hline \multirow{3}{*}{ Executor } & $\begin{array}{l}\text { Article } 3 \\
\text { paragraph } \\
\text { (1) letter a }\end{array}$ & $2 \%$ & $\begin{array}{l}\text { Service Providers } \\
\text { who have small } \\
\text { business } \\
\text { qualifications }\end{array}$ & \multirow{5}{*}{$2 \%$} \\
\hline & $\begin{array}{l}\text { Article } 3 \\
\text { paragraph } \\
\text { (1) letter c }\end{array}$ & $3 \%$ & $\begin{array}{l}\text { Service Providers } \\
\text { who have } \\
\text { medium business } \\
\text { qualifications or } \\
\text { large business } \\
\text { qualifications }\end{array}$ & \\
\hline & $\begin{array}{l}\text { Article } 3 \\
\text { paragraph } \\
\text { (1) letter b }\end{array}$ & $4 \%$ & $\begin{array}{l}\text { Service Providers } \\
\text { who do not have } \\
\text { business } \\
\text { qualifications }\end{array}$ & \\
\hline \multirow{2}{*}{$\begin{array}{l}\text { Planner and } \\
\text { Supervisor }\end{array}$} & $\begin{array}{l}\text { Article } 3 \\
\text { paragraph } \\
\text { (1) letter d }\end{array}$ & $4 \%$ & $\begin{array}{l}\text { Service Providers } \\
\text { who have } \\
\text { business } \\
\text { qualifications }\end{array}$ & \\
\hline & $\begin{array}{l}\text { Article } 3 \\
\text { paragraph } \\
\text { (1) letter e }\end{array}$ & $6 \%$ & $\begin{array}{l}\text { Service Providers } \\
\text { who do not have } \\
\text { business } \\
\text { qualifications }\end{array}$ & \\
\hline
\end{tabular}

The important thing that Law and income tax is not final based distinguishes between final tax on Article 23 Paragraph (1) letter c imposition based on Article 4 number 2 Income Tax Law is the Paragraph (2) letter d of Income Tax existence of business qualifications. 
Explanation of Article 3 paragraph (1) letter a PP No. 51 of 2008 juncto PP No. 40 of 2009 explains that "What is meant by" business qualifications "is the stratification determined based on the certification issued by the Construction Services Development Institute".

Thus it can be concluded that the distinguishing characteristics between the imposition of income tax on construction services that are final and which are non-final are business qualifications. If the construction service agent has business qualifications, then tax is imposed based on Article 4 Paragraph (2) letter $\mathrm{d}$ of the final Income Tax Law. And if the construction service agent does not have business qualifications, then tax is subject to Article 23 Paragraph (1) letter c number 2 of the Income Tax Law.

\section{Legal Certainty}

A taxation system must reflect the values of justice, legal certainty, business purpose concept, there is ease in making payments and according to the ability of taxpayers who must bear the tax burden ${ }^{18}$. Legal certainty shows that there are no biased and discriminatory regulations in the preparation and implementation of existing tax regulations.

${ }^{18}$ S. M. Jones, Principles of Taxation for Business and Investment Planning, Internatio (Mc Graw-Hill, N.Y, 2007), p. 24.
Certainty in legislation as explained by Adam Smith in his book "An Inquiry into Nature and Causes of the Wealth of Nations", better known as The Four Maxims ${ }^{19}$, that tax regulations must aim to provide legal certainty. While the definition of legal certainty is indeed there is no conformity of understanding, but the definite meaning is that the provisions of the law may not give doubt.

Laws and regulations must be applied consistently for the same situation continuously, so that the law must be arranged in such a way that it will not provide an opportunity for anyone to provide an interpretation that is different from what is desired by the legislators.

Legal certainty in other civil law from legal certainty in public law. In civil law besides dwingend recht (coercive), there is also aanvullendrecht (regulating). Civil law provides an opportunity for parties to self-regulate relations between them so that they themselves are obliged to seek legal certainty between them. As with public law, in this case the tax law is the one that must be obeyed by the public or everyone $^{20}$. So that the provisions of the law must be clear and firm, and do not provide an opportunity for anyone

\footnotetext{
${ }^{19} \mathrm{R}$. Santoso Brotodihardjo, Introduction to Tax Law (Bandung: PT. Eresco, 1984), pp. 2538.

${ }^{20}$ Rochmat Soemitro, Tax Law Principles (Jakarta: National Legal Development Agency Ministry of Justice, 1991), p. 16.
} 
to provide another interpretation of the wishes of the legislators.

To fulfill the provisions of the principle of legal certainty in tax collection, we need to pay attention to certainty in several respects, namely ${ }^{21}$ :

1. It must be certain, who should be taxed;

2. It must be certain, what is the basis for taxing the subject of taxes;

3. Must be certain, how much must be paid based on the tax rate;

4. It must be certain, how much the tax owed must be paid.

In addition, Van Apeldorn proposed two notions of legal certainty, as follows ${ }^{22}$ :

1. Legal certainty means that what law can apply to concrete problems can be determined. With concrete problems can be determined, the litigant parties can already know from the beginning what provisions will be used in the dispute.

2. Legal certainty means legal protection, in this case the parties to the dispute can be avoided from the arbitrariness of judgment by the authorities.

In terms of taxpayers, although they do not provide direct added value, compliance with tax obligations can be considered as a form of loyalty and participation at the expense of administering government and a form

${ }^{21}$ R. Mansury, Advanced Income Tax (Jakarta: Ind-Hill Co., 1996), p. 5.

${ }^{22}$ Peter Mahmud Marzuki, Legal Research (Jakarta: Kencana, 2005), pp. 59-60. of solidarity to create shared prosperity with the condition that legal certainty ${ }^{23}$.

\section{Conflict of Rules for Imposing Income Tax on Construction Services}

The regulation of income tax on construction services is regulated in two different articles on the Income Tax Law, namely Article 4 Paragraph (2) letter $d$ of the final Income Tax Law and Article 23 Paragraph (1) letter c number 2 of the Income Tax Act which is not final clearly can be distinguished through the existence of business qualifications owned by construction service actors as stated in the explanation of derivative rules of Article 4 Paragraph (2) letter d of the Income Tax Law, namely Article 3 paragraph (1) letter a PP No. 51 of 2008 juncto PP No. 40 of 2009. This means that if the construction service agent has business qualifications, then tax is imposed based on Article 4 Paragraph (2) letter $d$ of the final Income Tax Law. And conversely, if the construction service agent does not have business qualifications, then tax is imposed based on Article 23 Paragraph (1) letter c number 2 of the Income Tax Law.

The rule conflict in the regulation of income tax on construction services

\footnotetext{
${ }^{23}$ Hartono Rahardjo, "Analysis of Business Friendly Aspects in the Income Tax Law and Value Added Tax on Goods and Services and Sales Tax on Luxury Goods", The 7th NCFB and Doctoral Colloquium 2014, 1978 - 652 (2014), p. 59.
} 
appears when it is associated with arrangements regarding business qualifications which become "key requirements" so that they fall into the category of construction services subject to Article 4 Paragraph (2) letter $\mathrm{d}$ of the final Income Tax Law.

Based on Article 3 paragraph (1) PP No. 51 of 2008 juncto PP No. 40 of 2009 concerning Income Tax on Construction Services Business, the imposition of the final income tax on construction services is differentiated based on the business qualifications owned by construction service actors, which in this case are divided into 4 (four) parts of business qualifications, namely:
a. Small
b. Middle class
c. Big
d. No Business Qualifications

Then, clearly explained in the explanation of Article 3 paragraph (1) letter a PP No. 51 of 2008 juncto PP No. 40 of 2009 that "What is meant by" business qualifications "is the stratification determined based on the certification issued by the Construction Services Development Institute". The Construction Services Development Agency (LPJK) is an institution established based on the implementing regulations of Law Number 18 of 1999 concerning Construction Services that carries out the task of certification and registration of business entities and construction workers. Law Number 18 Year 1999 concerning Construction
Services has been replaced by Law Number 2 of 2017 concerning Construction Services. However, the existence of the LPJK continues to be recognized as stated in Article 103 of Act Number 2 of 2017 concerning the Construction Services.

The imposition of income tax on construction services based on the derivative rules of Article 4 paragraph (2) of the Income Tax Law has qualifications that do not have business qualifications. Meanwhile according to the Construction Services Law itself, there is no qualification without business qualifications. This shows that there is a conflict in the rules regarding the regulation of income tax on construction services, especially in the qualifications of not having business qualifications regulated also in the derivative rules of Article 4 paragraph (2) of the Income Tax Law.

Arief Sidhartaexplains that the rules are blurred as "vague understanding". A vague definition is an understanding whose contents cannot be determined exactly, so that the scope is not clear. About an understanding can be said that the understanding has a core that is more or less clear, whose scope can be determined exactly, but that around it there are unclear boundaries whose scope cannot be determined exactly ${ }^{24}$.

This is also in accordance with Philipus M. Hadjon and Tatiek Sri

\footnotetext{
${ }^{24}$ Arief Sidharta, Reflections on Law (Bandung: Citra Aditya Bakti, 1999), p. 61.
} 
Djatmiati's explanation in his book Legal Arguments that with conflict the rules will raise problems in the form of contradictions between the rule of law of related regulations which are jointly applied when facing a legal case ${ }^{25}$.This conflict of rules between tax regulations and construction service regulations can lead to difficulties in implementing a provision for the community, especially when faced with legal cases between taxpayers and tax officers (tax authorities).

\section{Rules of Conflict Resolution}

In the event of a conflict of rules, the focus of the problem is related to the obscurity of a rule in a law. In addition to causing problems, rule conflicts can also lead to legal uncertainty in the application of these provisions to the community.

To answer the problem of rule conflicts, legal analysis steps are needed (legal problem solving) ${ }^{26}$ through legal interpretation (rechtsinterpretatie) which aims to provide an unclear explanation of the text of the law so that the scope of the law can be determined in connection with certain events ${ }^{27}$.

The interpretation of laws and regulations relating to tax laws and related regulations is seen as something special and an extraordinary problem.

\footnotetext{
${ }^{25}$ Philipus M. Hadjon and Tatiek Sri Djatmiati, Legal Arguments, Prints to (Yogyakarta: Gajah Mada University Press, 2014), p. 31. ${ }^{26}$ Ibid h. 40

${ }^{27}$ http://lawyer.fahrul.com/2011/12/penafsiranhukum-rechtsinterpretatie.htmlaccessed on December 14, 2018
}

Government apparatus as the executor of the law, in this case the tax officer (tax authorities) against the laws and regulations in the field of taxation will certainly use all means of interpretation that are allowed to collect as much tax as possible. Conversely according to the Taxpayer, looking at taxes as a burden that will reduce "the contents of the bag", because the tax must be paid from income or wealth ${ }^{28}$.

The legal interpretation (rechtsinterpretatie) conducted on this issue aims to achieve legal certainty. Bruggink in Philipus M. Hadjon and Tatiek Sri Djatmiati ${ }^{29}$ classify various interpretations in 4 (four) models, namely:

1. Language interpretation (de taalkundige interpretatie)

2. Historical laws (de wetshistorische interpretatie)

3. Systematic (de systematische interpretatie)

4. Community (de maatshappelijke interpretatie)

Whereas it relates to interpretation, McLeod in Philipus M. Hadjon and Tatiek Sri Djatmiati ${ }^{30}$, put forward 3 (three) principles in contextualism, namely:

1. Principle of Noscitur a Sociis That is, a word must be interpreted in the sequence.

2. Principle of Ejusdem Generis

\footnotetext{
${ }^{28}$ R. Santoso Brotodihardjo, Introduction to Tax Law, Prints Ke (Bandung: PT. Eresco, 1993), p. 165.

${ }^{29}$ Op. cit h. 26

${ }^{30}$ Op. cit h. $26-27$
} 
That is, one word is limited to meaning specifically in the group.

3. The Expressio Principle of Unius Exclusio Alterius

That is, if one concept is used for one thing, it means it does not apply to other things.

Three principles in the contextualism, their use must be done sequentially.

\section{Certainty of Law for Imposing Income Tax on Construction Services}

The starting point for analyzing this problem, especially in the case of business qualifications, does not have business qualifications that exist in the imposition of income tax on construction services subject to Article 4 paragraph (2) of the Income Tax Law. In fact, if referring to the regulation regarding business qualifications that become "key conditions" so that they are included in the category of construction services subject to Article 4 Paragraph (2) letter $\mathrm{d}$ of the final Income Tax Law, there is a business qualification. That is, if you do not have business qualifications then you are not subject to Article 4 Paragraph (2) letter $d$ of the Income Tax Law, should be subject to Article 23 of the Income Tax Law.

Analysis is carried out on legislation related to business qualifications through a statute approach because what is examined are various laws and regulations that regulate business qualifications which are the focus as well as the central theme in this research and the conceptual approach that done by understanding the elements of business qualifications that exist in the legislation governing the qualifications of the business ${ }^{31}$.

Explanation in Article 3 paragraph (1) letter a PP No. 51 of 2008 juncto PP No. 40 of 2009 provides a "signal" that this provision applies to construction service operators who have business qualifications, so this regulation is of a nature lex specialis derogat legi generali 32 .Therefore, construction service businesses that do not have business qualifications based on certification issued by LPJK, if construction service business actors are in the form of business entities, are subject to tax based on Article 23 paragraph (1) letter c number 2 of the Income Tax Act, and if the perpetrator construction services business is in the form of individuals, subject to tax based on Article 21 of the Income Tax Law. However, the unclear mention of the form of business of construction services, business entities or individuals, subject to tax rates based on this provision, provides its own problems which ultimately lead to legal uncertainty.

To provide legal certainty regarding this obscurity, it is necessary to compare business qualifications

\footnotetext{
${ }^{31}$ Op. cit h. $245-252$

${ }^{32}$ Ahmad Rifai, Law Discovery by Judges in Progressive Legal Perspective (Jakarta: Sinar Grafika, 2010), p. 90.
} 
according to the income tax laws and regulations regarding business qualifications according to the laws and regulations of construction services. This pairing is done to clarify interpretations that are based on 3 (three) principles in contextualism.

Erly Suandy stating that tax is imposed because there is a subject which is fulfilling the criteria set out in the tax regulations. So that there is an assertion that if there is no tax subject, then clearly PPh cannot be imposed ${ }^{33}$.

Interpreting business qualifications has fulfilled 3 (three) principles in contextualism, namely:

\section{Principle of Noscitur a Sociis}

That is, a business qualification word aimed at one particular criterion in the income tax legislation must be related to a qualifying word according to these criteria.

2. Principle of Ejusdem Generis

This means that one business qualification word issued by the LPJK is specifically limited in its group according to legislation.

3. The Expressio Principle of Unius Exclusio Alterius

That is, if one concept of business qualification has been used for one thing, then it does not apply to another.

With this interpretation, it is able to answer vague norms for business qualifications that have not been answered so far to provide legal

${ }^{33}$ Erly Suandy, op. cit, h. 43 certainty for construction service business actors. By interpreting this, the imposition of income tax on construction services has been fulfilled in several ways that cause certainty, namely ${ }^{34}$ :

1. It must be certain, who should be taxed

This interpretation clarifies the parties who are subject to tax on construction services based on ownership of business qualifications issued by the LPJK or not.

2. It must be certain, what is the basis for taxing the subject of tax.

Income that is earned or received by the perpetrator of construction services is a clear basis for taxing construction services.

3. Must be certain, how much must be paid based on the tax rate

Clear interpretation of the qualifications of the construction services business also provides clarity and certainty about the amount of tax rates imposed on construction service operators.

4. It must be certain, how much the tax owed must be paid.

The amount of tax payable is known from the tax base multiplied by the amount of the tax rate, must be deposited through the perception bank as well as the post office that has been designated by the Directorate General of Taxes as the recipient of the tax deposit.

\footnotetext{
${ }^{34}$ R. Mansury, op. cit, h. 5
} 
To clarify the interpretation in order to resolve conflict rules regarding the qualifications of this construction service business, it can be resolved by the principle of legal preference.

Regulations regarding business qualifications do not have business qualifications in the construction services category subject to Article 4 Paragraph (2) letter $d$ of the final Income Tax Law stipulated in PP No. 51 of 2008 juncto PP No. 40 of 2009. The concept of Construction Services subject to Article 4 Paragraph (2) letter $\mathrm{d}$ of the Income Tax Law is one that has business qualifications. Whereas Construction Services subject to Article 23 of the Income Tax Law are those who do not have business qualifications.

So, based on the principle of superiory lex derogation, then Article 23 of the Income Tax Law is superior to Article 3 of PP No. 51 of 2008 juncto PP No. 40 of 2009. As such, referring to the regulation regarding the qualifications of construction services business that become "key conditions" to be included in the construction services category subject to Article 4 Paragraph (2) letter d of the final Income Tax Law, then if you do not have business qualifications then not subject to Article 4 Paragraph (2) letter $\mathrm{d}$ of the Income Tax Law, but subject to Article 23 of the Income Tax Law.

\section{Conclusion}

From the discussion above, two conclusions can be drawn, namely:

a. The characteristic that distinguishes the imposition of income tax on final construction services with the imposition of income tax on nonfinal construction services is the business qualifications owned by construction service actors, both construction service actors in the form of business entities and construction service agents in the form of individuals. If the construction service agent has business qualifications, then the income tax will be subject to Article 4 Paragraph (2) letter d of the final Income Tax Law. And if the construction service agent does not have business qualifications, then the income tax will be subject to Article 23 Paragraph (1) letter c number 2 of the Income Tax Law for construction service actors in the form of business entities and subject to income tax based on Article 21 of the Income Tax Law for construction services in the form of individuals.

b. The interpretation and / or principle of legal preference that has fulfilled 3 (three) principles in contextualism is able to answer vague norms which have so far provided legal uncertainty regarding the imposition of income tax on construction services. 
Arrangements regarding business qualifications become "key conditions" in the construction services category subject to income tax Article 4 Paragraph (2) letter d of the final Income Tax Law. and if it does not have business qualifications then it is not subject to income tax Article 4 Paragraph (2) letter d of the Income Tax Law, but subject to income tax Article 23 of the Income Tax Law.

\section{Suggestion}

The results of this study provide suggestions for improvement, namely:

a. The Government and the House of Representatives (DPR) need to conduct a comprehensive review of the provisions of laws and regulations in the field of taxation, especially related to Income Tax (PPh) for construction services that are able to provide legal certainty for all construction service business actors.

b. The Government and Parliament need to revise the provisions of laws and regulations in the field of taxation, especially regarding $\mathrm{PPh}$ on construction services to be in line with the provisions of legislation in the field of construction services, so as not to cause conflict of rules.

\section{BIBLIOGRAPHY}

Ahmad Rifai, Legal Discovery by Judge in Progressive Legal Perspective, Sinar Grafika, Jakarta, 2010.

Ali, H. Zainuddin, Legal Research Method, Second Printing, Sinar Grafika, Jakarta, 2010.

Arief Sidharta, Reflections on Law, Citra Aditya Bakti, Bandung, 1999.

C.S.T Kansil, Introduction to Indonesian Law and Law, Balai Pustaka, Jakarta, 1989.

Erky Raharja, Tax Aspect for Construction Services To Fulfill Tax Obligations at PT Tiga Muara Jaya Surabaya, Accounting, STIE Perbanas, 2014.

Erly Suandy, Tax Law Issue 5, Publisher Salemba Empat, South Jakarta, 2011.

Hartono Rahardjo, Analysis of Business Friendly Aspects in the Income Tax Law and Value Added Goods and Services Tax Law and Sales Tax on Luxury Goods, The 7th NCFB and Doctoral Colloquium 2014, ISSN NO: 1978 - 652, Widya Mandala Catholic University, Surabaya, 2014. Http:/ lawyer.fahrul.com/2011/12/pe nafsiran-hukumrechtsinterpretatie.htmlacce 
ssed on December 14, Mezak, Meray Hendrik, Types, 2018.

Http://ortax.org/ortax/?mod=info\&p age $=$ show\&id $=168 \&$ list $=1$ accessed on December 12, 2018.

Http://www.pajak.go.id/content/belaj ar-pajakaccessed on December 16, 2018.

Indah Kurnia, Legal Analysis of Tax Payments for Underpaid Corporate Income Tax PT. Sulselbar Regional Development Bank, Faculty of Law, Hasanunddin University, Makassar, 2013.

Indriyawati, Collection of Income Tax on Income from Construction Services in the State-Owned Enterprise Tax Service Office in Jakarta, Diponegoro University, Semarang, 2009.

Johnny Ibrahim, Theory and Methodology of Research in Administrative Law, Second Matter, Bayumedia Publishing, Malang, 2005.

Jones, S. M., Principles of Taxation for Business and Investment Planning, Mc Graw-Hill, N.Y. International Edition, 2007.

Mardiasmo, Taxation Revised Edition 2011, CV Andi Offset, Yogyakarta, 2011.
Methods, and Approaches in Legal Research, Law Review. Pelita Harupan University Law Faculty, Vol. V, No. 3. March 2006.

Ministry of Public Works and Public

Housing, Construction

Sector Occupies Third

Position in Supporting Indonesian Economic Growth 2016, accessed from

http:/ /www.pu.go.id/berit a/12187/Sektor-

Konstruksi-Tempati-PosisiKetiga-Penyokong-

Pertumbuhan-EkonomiIndonesia-2016 accessed on 10 October 2018.

Monica Raditya, Evaluation of Income Tax on Construction Services (Case Study at PT. Concretindo Citra Sarana), Sanata Dharma University, Yogyakarta, 2016.

Muhammad Rasul, Tax Treatment for Construction Services, Perbanas Review Volume 1, Number 1, Accounting, Perbanas Institute, 2015.

Nor Hasan, The Effect of Self Assessment System and Fiscal Services on Formal Compliance of Taxpayers (Study at Surabaya Middle Tax Office), FEB Airlangga University, 2017. 
Peter Mahmud Marzuki, Legal Research, Kencana, Jakarta, 2005.

Peter Mahmud Marzuki, Legal Research, Eleventh Prints, Kencana, Jakarta, 2011.

Philipus M. Hadjon and Tatiek Sri Djatmiati, Legal Arguments, Sixteenth Prints, Gajah Mada University Press, Yogyakarta, 2014.

R. Mansury, Advanced Income Tax, Jakarta: Ind-HillCo., 1996.

R. Santoso Brotodihardjo, Introduction to the Tax Law Science, PT. Eresco, Bandung, 1984.

R. Santoso Brotodihardjo, Introduction to Tax Law, Seventeenth Mold, PT. Eresco, Bandung, 1993.

Rizkya Harum Handayani and Liberti Pandiangan, Evaluation and analysis of fulfillment of corporate $\mathrm{PPh}$ tax obligations in construction service companies (case study of PT. Bumi Adhi Gas), Accounting, Bina Nusantara University, 2013.

Rochmat Soemitro, Tax Law Principles, Jakarta: National Law Development Guidance Department of Justice, 1991.

Romi Handoko, Income Tax in Review of Islamic Law, Faculty of
Sharia, Sunan Kalijaga State Islamic University, 2009.

Soejono and H. Abdurrahman, Legal Research Methods, Second Print, PT. Rineka Cipta, Jakarta, 2003.

Syamsudin, Operationalization of Legal Research, PT. RajaGrafindo Persada, Jakarta, 2007.

C.I Violencia. Kondoy, Grace B. Nangoi, and Inggriani Elim, Analysis of the application of construction services income tax on CV. Horizon, Scientific Periodical Journal of Efficiency Volume 16 No. 04, Accounting, Sam Ratulangi University, Manado, 2016.

Waluyo, Bambang, Legal Research in Practice, Fourth Mold, Sinar Grafika Offset, 2008.

Wirawan B. Ilyas and Richard Burton, Tax Law Issue 5, Salemba Empat, Jakarta, 2010.

Yul Yarnita, Income Tax Analysis of Construction Services at PT. Stabilished Pavement Indo, Accounting, UIN Sultan Syarif Kasim Riau, 2013. 